\title{
Towards efficient capital flow management
}

Ángel Estrada, Luis Molina, Paula Sánchez and Francesca Viani

Financial globalisation has advanced notably in recent decades. In principle, greater integration should raise the degree of economic efficiency. However, the empirical evidence suggests that, for this to occur, countries should have well-designed economic institutions and sufficiently developed local financial markets. Moreover, these flows may jeopardise financial stability in certain circumstances, whereby the economic authorities need to draw on criteria and instruments to withstand such situations. These tools should be used as part of a broader programme of measures that includes the macro and microeconomic adjustments required. Furthermore, international cooperation emerges as a necessary complement to globalisation. 
The authors of this article are Ángel Estrada, Luis Molina, Paula Sánchez and Francesca Viani of the Associate Directorate General International Affairs.

Financial globalisation has advanced notably in recent decades. In principle, greater integration should raise the degree of economic efficiency. However, the empirical evidence suggests that, for this to occur, countries should have well-designed economic institutions and sufficiently developed local financial markets. Moreover, these flows may jeopardise financial stability in certain circumstances, whereby the economic authorities need to draw on criteria and instruments to withstand such situations. These tools should be used as part of a broader programme of measures that includes the macro and microeconomic adjustments required. Furthermore, international cooperation emerges as a necessary complement to globalisation.

Introduction

Economic and financial globalisation is once again at the centre of academics' and economic policymakers' concerns. Against the background of greater integration and fewer obstacles to cross-country movements in financial flows, it would be reasonable to expect these flows to be targeted on those areas where they can obtain a higher return, resulting in higher global growth. In this way, countries with sound growth expectations would receive financing from abroad, raising their welfare level by virtue of their being able to bring forward a portion of their future income, while countries with surplus saving will be able to diversify their investment portfolios, thereby hedging against idiosyncratic shocks.

However, financial globalisation also has potential costs, since it raises economies' external exposure, heightening their vulnerability to external shocks and making them more dependent on the global financial cycle. Indeed, after three decades of gradual financial liberalisation in most countries, certain stylised facts have been observed which mean that the simplistic view that greater liberalisation entails greater gains for all needs to be qualified.

Firstly, financial resources do not appear to flow from countries where they are most abundant (and their marginal return lower) towards countries where they are scarce (and their marginal return higher); rather, the opposite is the case. In fact, the direction of capital flows appears to be influenced by the quality of economic institutions and the level of financial development of the recipient country, conditions that are necessary to obtain the maximum benefits from these flows. Secondly, their effect differs depending on how they are instrumented. Specifically, foreign direct investment and equity portfolio investment, as well as being more stable, contribute to absorbing shocks, while debt flows amplify such shocks and evidence high volatility.

Accordingly, the idea that countries should strengthen their institutions and develop their financial systems before liberalising their financial account has gained ground. It is likewise accepted that in certain circumstances the authorities may use tools designed to manage capital flows, especially if there are risks to the country's financial stability. However, it is recommended that these measures should be temporary and that they should under no circumstances be a substitute for the macro and microeconomic adjustments the economy requires. 
Recent developments in capital flows

This article first describes the main stylised facts relating to the behaviour of capital flows in recent decades. Second, it reviews the factors that drive capital flows and their impact. Lastly, we set out the economic policy options available to the authorities to obtain most benefit from external financing flows and minimise their adverse effects.

One of the most significant stylised facts of the global economy in recent years has been the gradual increase in the interrelatedness of the different economies. Economic globalisation first materialised in the trade domain. But from the year 2000 in particular, financial integration has been most intense. Just as the promotion of imports and exports requires a lowering of tariff and non-tariff trade barriers between countries, for agents to carry out financial trades, financial accounts must be sufficiently liberalised and not subject to significant restrictions. If the degree of openness of the financial account is measured using a de iure index, such as that devised by Chinn e Ito (2006), financial globalisation can be seen to have undergone boosts in 1991 and 2000 (along with a regression in 1995 following the Mexican crisis and the emerging country crises that followed it), peaking in 2008 (see Chart 1.1). After the global financial crisis (GFC), the degree of openness fell off slightly, especially among the emerging economies. This index also illustrates how the advanced economies have more liberalised financial accounts than their emerging counterparts, whose level of openness at present is similar to that the advanced economies had in the 1980s.

A complementary form of analysing the degree of liberalisation of the financial account is to examine changes in de facto indicators, such as the weight of external assets (and liabilities) globally and in the various economies. As can be seen in Chart $1.2^{1}$, from 1980 to 2000 the weight of financial assets in global GDP climbed from $31 \%$ to $100 \%$, and virtually doubled in the seven following years, up to the 2008 crisis. From GFC on, GDP growth has outpaced that of global financial assets, whereby in 2015, on the latest aggregate figure available, their weight stood at around 190\% of GDP, some 10 pp below the historical high. In line with the Chinn and Ito indicator, external assets account for a much lower percentage in the emerging economies than in the advanced ones. Moreover, the fall in the level of financial globalisation that this indicator reflects after the GFC is due to the behaviour of the emerging economies, where financial assets declined from $63 \%$ to $53 \%$ of the GDP of these countries from 2007 to 2015, as a result of the decline in Middle East assets, following the collapse in oil prices; in the case of Latin America, assets increased by 13 pp of regional GDP from 2007 to 2015.

Chart 1.3 shows the capital flows that have given rise to the build-up of the stocks analysed in the foregoing paragraph, where their marked fluctuations can be seen: global gross flows increased gradually from 2000 to peak at close to $20 \%$ of global GDP in 2007; during the global financial crisis they diminished drastically, even becoming negative (which reflects the intensity of capital repatriation by foreign investors to their countries); subsequently, they increased once again, but without reaching pre-crisis levels. As could be construed from what happened with the stocks of assets and liabilities, it is the advanced economies that record the bulk of capital flows; hence, the decline in flows during the crisis was much greater in the advanced economies, while the emerging countries continued to post gross capital inflows during this period. Nonetheless, more

1 In theory, the level of global external assets and liabilities should be the same, but in practice measurement errors and data compilation discrepancies mean that this identity does not hold. In the charts below the discrepancies between gross flows of assets and liabilities are not very sizeable (less than $1 \%$ of GDP), and they stem in particular from the portfolio flows item. 


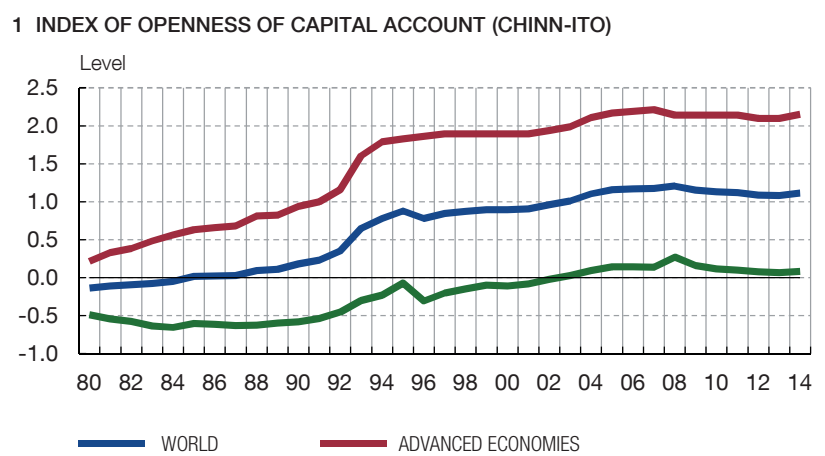

3 GROSS CAPITAL INFLOWS (a)

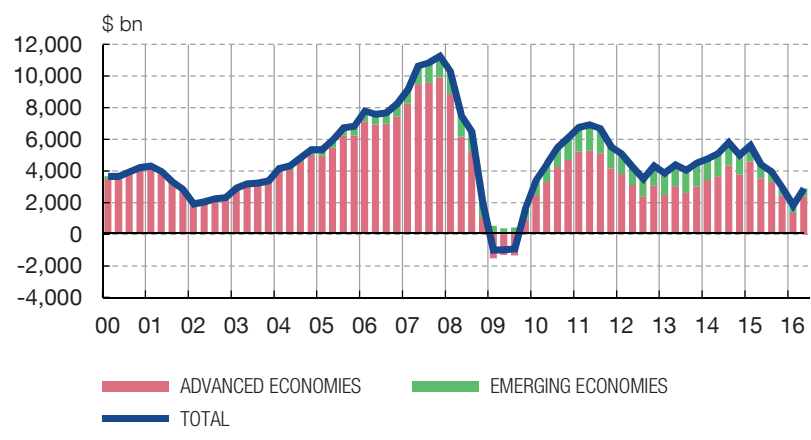

5 GROSS CAPITAL INFLOWS: ADVANCED ECONOMIES (a)

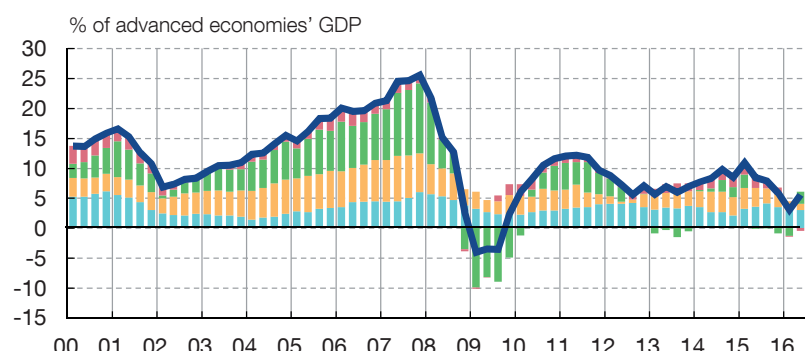

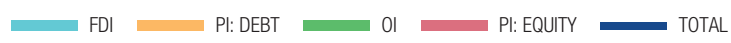

7 GROSS CAPITAL OUTFLOWS: ADVANCED ECONOMIES (a)

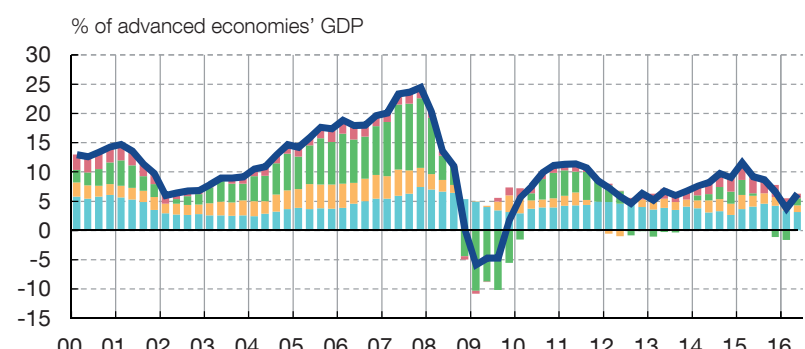

$\begin{array}{lllllllllllllllll}00 & 01 & 02 & 03 & 04 & 05 & 06 & 07 & 08 & 09 & 10 & 11 & 12 & 13 & 14 & 15 & 16\end{array}$

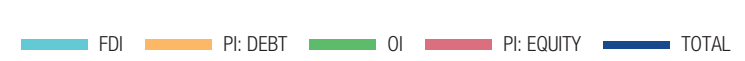

\section{WORLD FINANCIAL ASSETS}

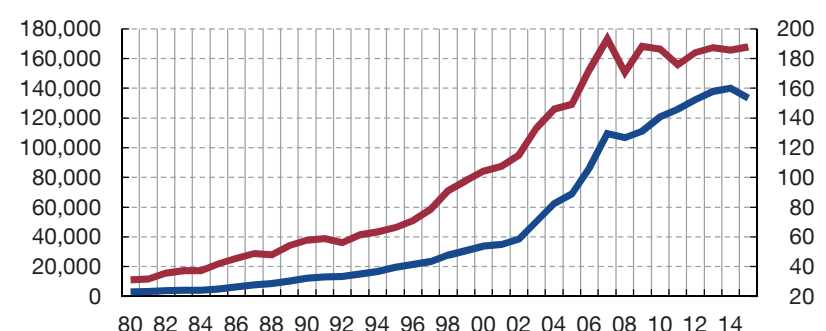

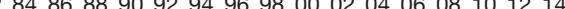

NOMINAL (\$bn) _ — \% OF GDP (right-hand scale)

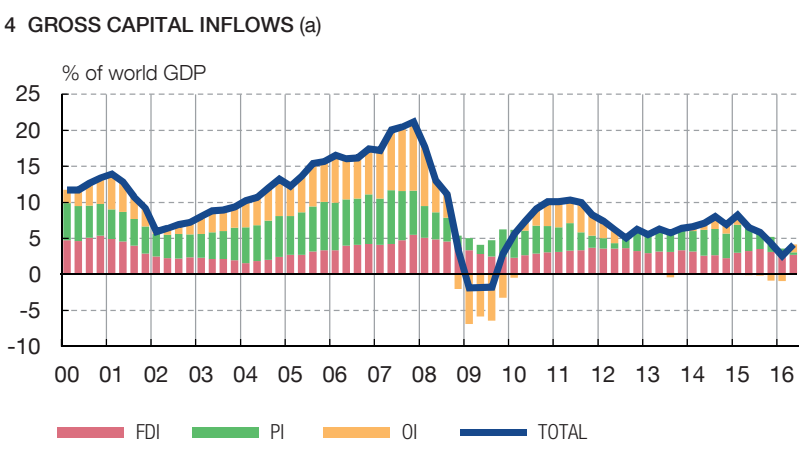

\section{GROSS CAPITAL INFLOWS: EMERGING ECONOMIES (a)}

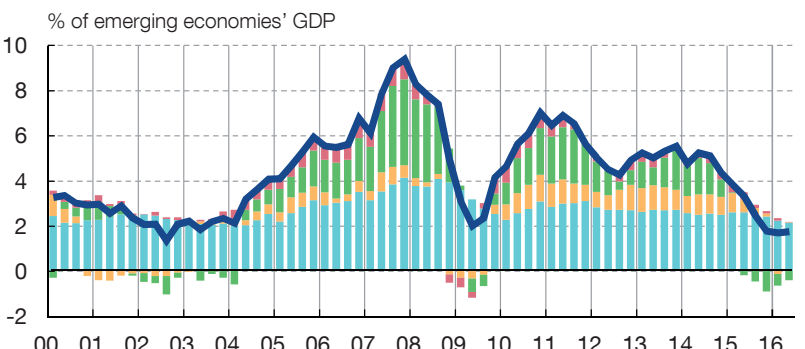

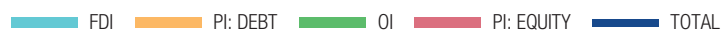

8 GROSS CAPITAL OUTFLOWS: EMERGING ECONOMIES (a)

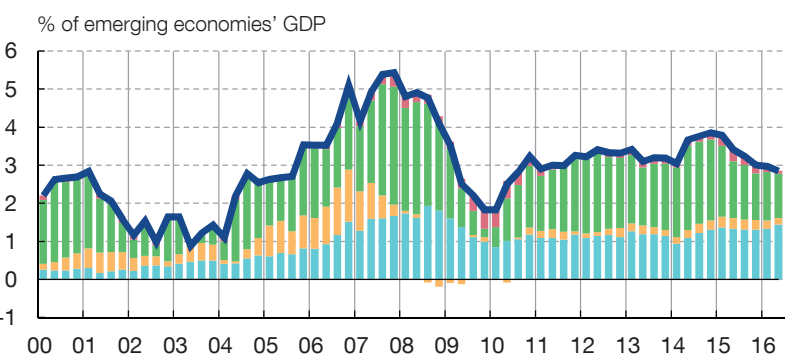

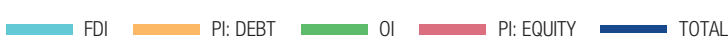

SOURCES: Banco de España, drawing on IMF, Datastream and Dealogic.

a Four-quarter moving sum. 
9 NET CAPITAL FLOWS: ADVANCED ECONOMIES (a)

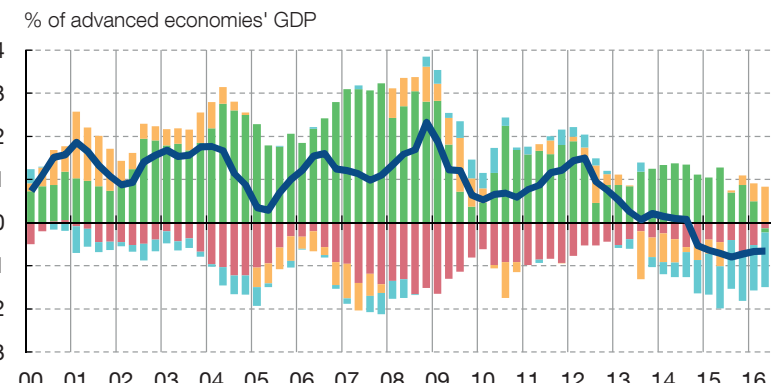

10 NET CAPITAL FLOWS: EMERGING ECONOMIES (a)

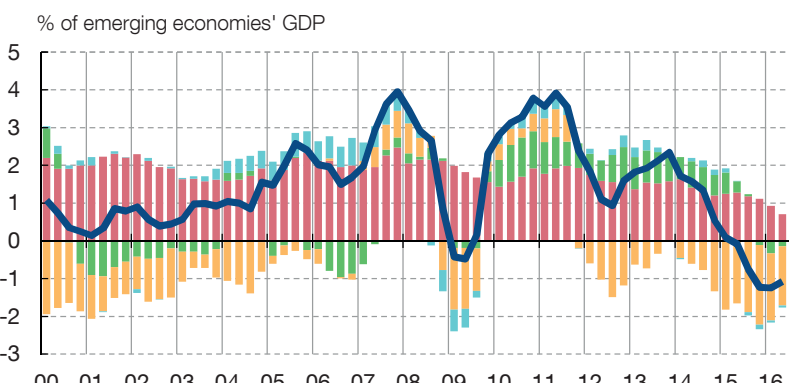

FDI

PI: DEBT

\section{VOLATILITY OF NET FLOWS}

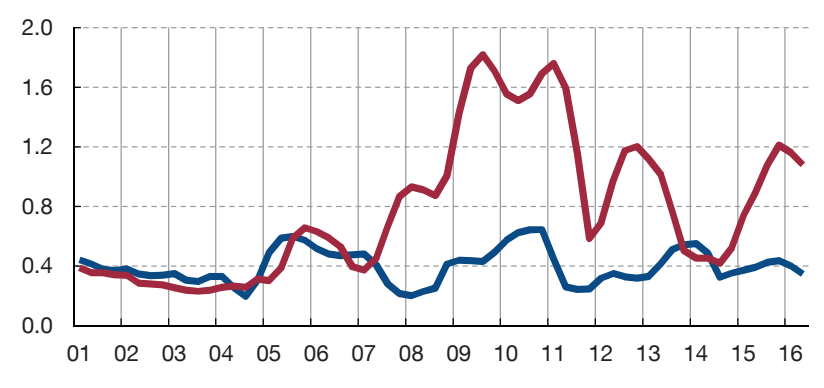

ADVANCED ECONOMIES

EMERGING ECONOMIES

\section{EMERGING ECONOMIES: FIXED-INCOME ISSUANCE ON INTERNATIONAL MARKETS}

$\$$ bn

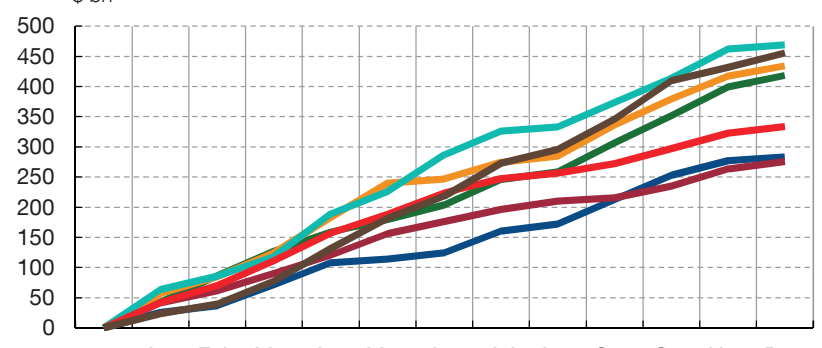

Jan Feb Mar Apr May Jun Jul Aug Sep Oct Nov Dec

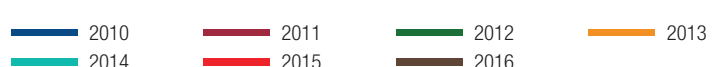

12 VOLATILITY OF NET FLOWS TO EMERGING ECONOMIES

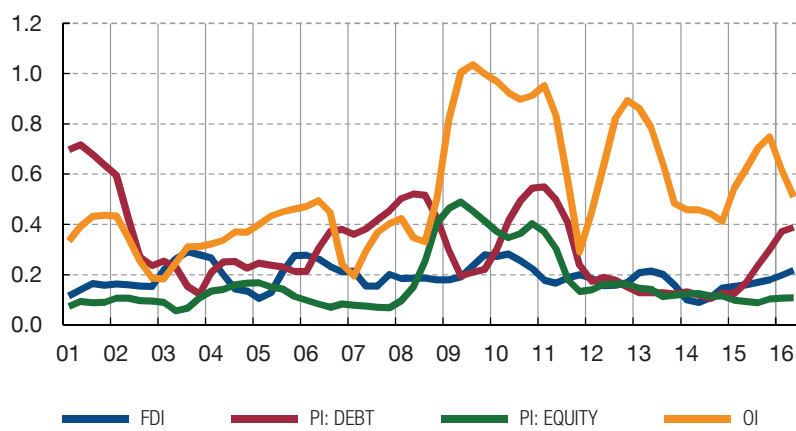

14 CONDITIONS OF FIXED-INCOME ISSUANCE ON INTERNATIONAL MARKETS (EXCLUDING SOVEREIGN BONDS)

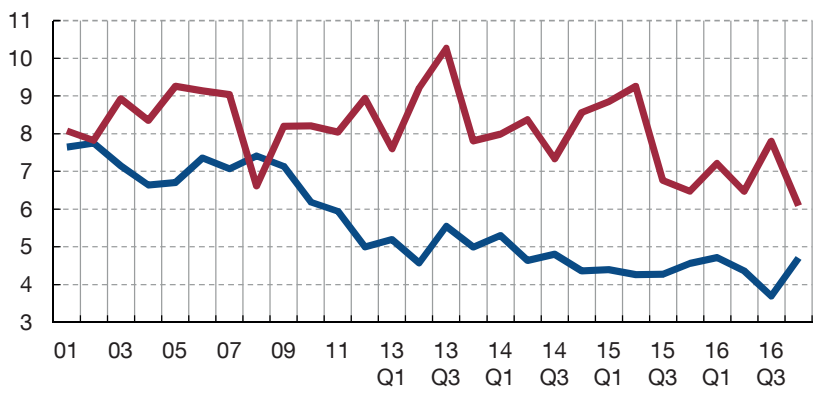

INTEREST RATE (\%)

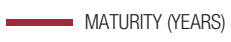

SOURCES: Banco de España, drawring on International Monetary Fund, Datastream and Dealogic.

a Four-quarter moving sum.

recently flows towards emerging markets have moved on a very significant declining trend, which is related to several factors such as the downward revision in the potential growth of these economies, the decline in commodities prices and the start of US monetary policy normalisation.

Capital flows encompass a wide variety of financial instruments. The most frequent classification groups flows under foreign direct investment (FDI), portfolio investment (PI) and other investment $(\mathrm{OI})$. Most of the FDI is by non-financial corporations, and in the main 
it is materialised in instruments which, like stocks, partially absorb the shocks that such assets may undergo. $\mathrm{PI}$ includes debt and capital instruments alike, and $\mathrm{Ol}$ is carried out above all by the banking sector, mainly through cross-border loans. As can be seen in Chart 1.4, the strong increase in pre-crisis capital flows was chiefly driven by cross-border banking flows - which rose from $2 \%$ of GDP in 2000-2001 to 10\% of GDP in 2007 - and by the smaller-scale increase in FDI and PI flows. The subsequent collapse in capital flows was centred both on banking and PI flows, while FDI remained relatively stable. Subsequently, PI has picked up to a greater extent than cross-border bank loans, partly as a result of the introduction of stricter banking regulations following the financial crisis.

Given the widely differing behaviour of capital flows in the advanced and emerging economies, it is worth analysing their composition in both areas ${ }^{2}$ separately. Hence Chart 1.5 shows how the strong increase in gross capital inflows in the advanced economies in the pre-crisis period chiefly took the form of bank loans and non-resident debt purchases. The 2008 collapse materialised in loans (in particular loans received from banks from other advanced economies), while the recovery observed in recent years has taken the form of bigger portfolio flows.

In the case of the emerging economies (see Chart 1.6), one initial fact to note is that FDI is the main flow ( $65 \%$ of flows in the period, against $25 \%$ in the advanced economies). The increase in flows received by these economies from 2000 to 2007 was on a lesser scale than that targeted on the developed countries (6 pp of GDP compared with $12 \mathrm{pp}$ in the advanced economies) and it took the form both of FDI (an increase of 2 pp of GDP) and bank loans (4 pp). Since 2009, inflows in the form of bank loans have held at very low levels (and were even negative from 2015), being partly replaced by debt instruments placed on international financial markets. Among the emerging economies, the recent decline in gross inflows has been more marked in Asia, owing to bank loans - in negative territory since early 2015 - and also to PI, which stood at $-0.1 \%$ of GDP in 2016 , compared with the figure of $1 \%$ observed in early 2015. In Latin America, FDI has held approximately at its pre-crisis percentages; moreover, it is the region that has seen the biggest increase in inflows in the form of debt (1.3 pp of GDP from 2009 to 2015). The higher frequency indicators of capital flows, drawn from other sources, suggest that, in the second half of 2016 and in January 2017, there have been portfolio capital outflows from the emerging economies, especially from stock markets, with such capital having been placed in the advanced economies, in private fixed-income assets.

In analysing the behaviour of capital flows, it is also worth looking at outflows, i.e. domestic agents' investment abroad. Occasionally, capital outflows tend to soften the financial constraint that might stem from a sudden reduction in inflows; they may also temper financial exuberance in times of plenty. As can be seen in Chart 1.7, in the wake of the collapse in 2008 (the so-called great retrenchment), capital outflows from the advanced economies recovered to levels below (once more) pre-crisis levels, as a consequence - as in the case of inflows - of the course of bank loans, which had been chiefly responsible for

2 The regional series depicted in the other charts have been compiled aggregating the respective balance of payments items of 19 advanced economies (United States, Japan, Germany, France, United Kingdom, Italy, South Korea, Spain, Canada, Australia, Netherlands, Belgium, Switzerland, Sweden, Singapore, Austria, Hong Kong, Norway and Luxembourg) and 41 emerging economies, 11 from Latin America (Brazil, Mexico, Argentina, Colombia, Chile, Venezuela, Peru, Ecuador, Uruguay, Panama and Bahamas), 8 from Asia (China, India, Indonesia, Thailand, Malaysia, Philippines, Bangladesh and Vietnam), 7 from Europe (Russia, Turkey, Poland, Hungary, Romania, Ukraine and Kazakhstan) and 15 from the rest of the world (Saudi Arabia, Iran, Egypt, Pakistan, United Arab Emirates, Algeria, Iraq, Nigeria, South Africa, Angola, Ethiopia, Kenya, Tanzania, Ghana and Morocco). The group of countries examined covers $92 \%$ of global GDP. 
their surge before the crisis. The composition of the outflows from the emerging economies is also very different from the outflows from the advanced countries (see Chart 1.8), with Ol predominant; that said, FDI is attaining similar levels. Gross outflows increased until 2008, especially in the form of FDI in Asia, and of OI in Asia and the Middle East.

Accordingly, the advanced economies maintained a positive net flow (inflows minus outflows) until end-2014 (see Chart 1.9). In terms of components, the net flow has traditionally been negative in the case of FDI, and also in that of net equity portfolio investment outflows, especially from 2015 (although the recent pick-up in stock market prices in the developed economies may reverse this situation). Net flows from the emerging economies have been uneven (see Chart 1.10), with a notable positive net flow in the case of FDI. At the aggregate level, they have turned negative in recent years, owing to OI and to debt PI flows.

The foregoing analysis focuses on the levels of capital flows; however, from the financial stability standpoint, it may be much more important to direct attention towards their volatility. Charts 1.11 and 1.12 show how, in the case of the advanced economies, volatility has tended to hover around a stable value; nonetheless, in the case of the emerging economies, which started at levels similar to those of the advanced economies, volatility increased considerably during the international financial crisis and without having recovered its prior stability subsequently. Factors such as the change in expectations about US monetary policy, the fall in commodities prices and the bouts of instability on the Chinese stock market would explain this development. In terms of types of flows, FDI and PI in equity have evidenced greater stability, while PI in debt and, above all, OI have behaved much more erratically, and their instability has increased in the wake of the global financial crisis.

As indicated, one of the most notable characteristics of capital flows following the 2008 global crisis has been the change in the composition of those received by emerging markets: debt instruments tradable on international markets have gained weight relative to bank loans (see Chart 1.10). Emerging economies' bond issues on international markets rose to historical highs year after year (with the exception of 2015) following the crisis (see Chart $1.13^{3}$ ), led initially by (Asian) non-financial corporations and banks, and subsequently by companies whose business is related to commodities. From 2015, inflows in the form of debt in the emerging economies declined, owing to fewer placements by these types of companies, which were partly replaced by sovereign issues. ${ }^{4}$ In parallel, to cover the possible risks arising from this increase in dollar-denominated debt, companies increased their placements on local markets, so most of the funds obtained by firms in some of the emerging regions were from such local markets. Also, an increase was seen in placements in currencies other than the dollar, especially in euro (which marked an all-time high in 2016). Financing conditions on international markets improved substantially after the crisis, with the strong decline in interest rates and the increase in maturities. So far, this improvement has not been reversed, despite the recent increase in long-term interest rates in the advanced economies (see Chart 1.14).

3 Data from Dealogic.

4 The increase in issues by commodities-producing firms has given rise to debate over their effects on global financial stability (see, inter alia, the IMF's October 2015 Global Financial Stability Report). Insofar as these firms incur debt in dollars, their positions appear to be naturally hedged, as the octane the revenue in the same currency; in practice, the correlation between the appreciation of the dollar and the fall in oil prices meant that some companies had financial difficulties. The situation is exacerbated in as much as the oil companies that became most indebted in recent times are State-owned. Regarding the general characteristics of the most indebted companies, see Fuertes and Serena (2015), who conclude that companies that issue on global markets have better financial ratios than those that do so on other markets. 
Proximate determinants of capital flows and economic impact
According to neoclassical economic principles, capital flows are responsive to crosscountry differences in profitability, so they should flow from the richer economies with higher volumes of capital and lower marginal returns towards those with a lower capital stock and a wider range of potentially profitable investments. Capital flows benefit the recipient country in various ways: (i) generating higher growth in the short and long term by increasing investment; (ii) allowing more stable patterns of consumption for its citizens, since a country which currently has low income but good growth prospects could borrow against future revenue, or lend when it is temporarily richer; (iii) improving allocation and production efficiency by raising the level of competition in domestic markets; (iv) reducing the vulnerability of countries, since diversifying the investment portfolio reduces exposure to idiosyncratic risks; and (v) improving the capacity to absorb local shocks owing to a greater integration with the rest of the world. ${ }^{5}$

However, as documented in the empirical literature, international capital flows have tended to flow "uphill" (from poor countries to rich countries) instead of "downhill", as theory predicts (Prasad et al., 2007). It should be borne in mind that the return on investment in countries with weak economic and political institutions, as occurs in many low-income countries, drops significantly when adjusted for the risk assumed. Additionally, capital flows tend to produce effects differing from those expected in recipient economies: thus, empirical studies do not, in general, support the idea that fewer barriers to capital inflows mean higher growth. On the contrary, there is evidence that emerging economies receiving lower capital flows grew faster than those with higher and sustained inflows (Rey, 2015, Prasad et al, 2007). Several studies point to possible adverse effects of financial account liberalisation, in the form of lower wages and significant and persistent increases in inequality (Furceri and Loungani, 2015). Also, capital inflows are characterised by high volatility, which feeds through to greater fluctuations in local macroeconomic variables and exposes the economy to potential shocks in the countries where the flows originate or in global financial conditions. In fact, capital inflows are associated with greater consumption volatility, with cycles of steep growth followed by sudden slowdowns, and with monetary mismatches which increase the risk of financial crises (Bluedorn et al., 2013, Rodrik, 2007).

Given the lack of empirical support for the theoretical advantages associated with liberalisation of the financial account in emerging economies, several studies have sought to identify the conditions under which capital inflows may be more beneficial. In this connection, the literature has focused on analysing the composition of capital flows. In general, flows in the form of long-term equities (FDI and PI) are preferable to flows of shortterm debt securities, which have often proved to be very volatile and potentially harmful (CGFS, 2009, Turner, 2010). Also, FDI has proved to be a useful instrument for the transfer of technology and knowledge.

Several studies also explore the existence of thresholds in the economic and institutional conditions of a country, which ensure that capital inflows have a positive effect. Evidence suggests that the interaction of a stable macroeconomic environment with efficient institutions (including sufficiently developed financial markets, an open trade regime, fiscal and price stability, and effective property rights) permits reasonable handling of risks and materialisation of capital flow benefits (Obstfeld, 2005, Mishkin, 2007). When a country does not meet these requirements, a strategy aiming to implement limited global financial integration, including appropriate regulatory instruments to reduce capital flow volatility, would be more efficient.

5 See, for example, Rodrik and Subramanian (2009), Kose et al. (2009), and Gourinchas and Jeanne (2013). 
The drivers of international capital flows are typically classified into two categories: push factors and pull factors. Pull factors are found in recipient countries (i.e. they are domestic factors) and include, inter alia, good growth prospects and macroeconomic stability which improve the risk-return profile of assets issued in a country and, which, therefore, contribute to attracting capital from abroad. Conversely, push factors are found in investor countries (i.e. they are external or global factors). They drive capital outwards owing to the comparatively lower return on investment in advanced economies or to the greater availability of liquidity. A major push factor driving capital towards emerging economies has been the reduction of interest rates in advanced countries, encouraging international investors to search for yield in the emerging markets.

From a regulatory viewpoint, it is important to establish which factors drive cross-border capital movements in practice: distinguishing pull factors from push factors is the first step in designing policies permitting the appropriate management of capital flows. When flows are driven mainly by country-specific characteristics, or when these characteristics play a significant role in determining the sensitivity of a country to global shocks, reducing the volatility of capital flows requires national authorities to improve the local environment by means of sound macroeconomic policies. By contrast, if the flows are driven by global factors, such as shifts in risk aversion or in financial conditions in the more systemic advanced economies, they could have undesirable effects for recipient countries, successively generating excessive asset and credit booms and busts, and increasing the risk of abrupt flow reversals. In this case, the sound macroeconomic policies required could be supplemented by additional measures, such as capital flow management tools and macroprudential policies.

The empirical literature generally finds that push factors are important drivers of capital flows. Indeed, many recent studies identify a clear relationship between interest rates in the major advanced economies and portfolio flows, since low interest rates spur investment in emerging markets, where yields are higher (the so-called search for yield, World Bank, 1997, Ghosh et al., 2014, Sarno et al., 2016). US monetary policy appears to play a particularly significant role in this connection. Financial conditions in the United States produce changes in the degree of uncertainty and risk aversion of international investors and generate simultaneous movements in capital flows, asset prices and credit growth worldwide, giving rise to the so-called "global financial cycle". For example, an expansionary monetary policy in the United States would reduce investors' risk perception, encouraging capital flows globally (Miranda-Agrippino and Rey, 2015, Bruno and Shin, 2015). However, the cyclical changes in investment flows, driven by financial conditions in the major advanced economies, might not be appropriate for the cyclical phase of a recipient economy. Under these circumstances, the use of financial account management measures to protect recipient economies from these investment flow fluctuations might be justified.

Nonetheless, the empirical evidence suggests that the sensitivity of each particular economy to push factors depends on the specific characteristics of the country in question. Specifically, the existence of deep domestic financial markets and a significant presence of global banks in the financial sector seem to increase sensitivity to global financial conditions (Cerutti et al., 2015, Eichengreen and Gupta, 2014). By contrast, high institutional quality protects both advanced and emerging economies against adverse shifts in global conditions (Fratzscher, 2012, Alonso, 2015). These results suggest that local authorities could reduce the vulnerability of their economies to global factors by encouraging the formation of an ample domestic investor base, having a substantial share of debt in 
Capital flow management instruments domestic currency and developing high-quality local institutions (Fratzscher et al., 2013, Alberola et al., 2016). Additionally, national authorities could take advantage of the heterogeneity of capital flows and promote specific conditions favouring the inflow of more stable and productive types of external investment, such as FDI, which, moreover, allow part of the effect of the shocks to be absorbed.

The preceding sections illustrate how global financial integration and the consequent higher volume of capital flows produce unquestionable benefits for both issuer and recipient countries (Caballero et al., 2015). However, global financial integration also makes countries more vulnerable because it facilitates the international transmission of shocks and raises countries' exposure to the global financial cycle, which plays an increasingly important role in determining countries' financial conditions (Eichengreen and Gupta, 2016). This dependence may generate risks for financial stability and hinder the management of monetary policy, particularly in small economies, where authorities have to be extremely mindful of external financial conditions. As mentioned above, the level of vulnerability will depend on the degree of development of local institutions, on the nature of inflows and on the currency in which they are denominated, among other factors.

This growing integration and high vulnerability has led a good proportion of academics and many international bodies entrusted with overseeing the smooth functioning of the global financial system to consider the advisability of having economic policy instruments to adjust capital flows and minimise their adverse effects. These instruments must be used in consonance with the nature and seriousness of the problem, and the most drastic of them, which limit or prohibit certain financial transactions, must be temporary; moreover, in no case can they act as a replacement for the required structural adjustments or an appropriate domestic macroeconomic policy stance. Some of these macroprudential instruments are based on the tools of microprudential supervision, aimed at lessening the aggregate risks assumed by the banking sector. Furthermore, it must not be overlooked that any international capital flow involves at least two parties, namely the issuing country and the recipient, so there is a certain shared responsibility which suggests the need to strengthen international cooperation.

The main challenge facing a recipient economy is coping with situations of withdrawal of capital flows, which may lead to a sudden stop or even a reversal. Under these circumstances, the first line of defence must be exchange rate flexibility, since exchange rate depreciation tends to counteract tighter external financial conditions through an increase in external demand associated with gains in competitiveness. However, sharp depreciation may also have negative consequences. Thus, if a significant portion of a country's debt were in foreign currency, as has been the usual practice in many emerging economies, depreciation could give rise to significant financial imbalances for the issuers of that debt. In this respect, it should be noted that in recent years many emerging countries have reduced the degree of foreign monetisation of their economies and simultaneously improved their economic institutions and the development of their financial systems. Moreover, depreciation may take place in a disorderly fashion, raising exchange rate volatility and increasing the hedging costs of operators in this market. Under these circumstances, having a sufficient volume of international reserves helps provide the necessary assurance.

Monetary and fiscal policies may also be used in situations of withdrawal of capital flows. Easing these policies may counteract tighter international financial conditions which constrain capital inflows. However, not all countries can take such action and on occasions 
they may be obliged to tighten such policies. Thus, in the case of monetary policy, exchange rate depreciation, since it raises the price of imports, may feed through to higher consumer inflation. If this inflation persistently exceeds the central bank's targets, it may have to raise interest rates. The degree of feed-through of exchange rate depreciation associated with a reversal of capital flows depends largely on the central bank's credibility and its past record of meeting its targets. As for fiscal policy, its use as a stabilisation mechanism requires a sustainable fiscal situation. In commodity-producing countries, international inflows may dry up as a result of the prices of these commodities having been adjusted downward. If a high percentage of fiscal revenue is associated with commodities, the only alternative may be to increase other public revenue or cut spending, so as to not jeopardise public finances sustainability.

To deal with imminent external crises or more complex situations, use has been made of measures to limit capital outflows (IMF, 2016). These measures, which are of a temporary nature, are usually imposed on specific currencies (rather than on nationalities) and on particular segments of the financial markets representing a specific risk. The tools included in this group of measures range from those of a fiscal nature, which act on financial instrument prices, to quantitative measures which limit or even prohibit certain transactions. The IMF (2016) reports that these measures are effective if implemented along with a macroeconomic adjustment programme, but that they also have costs in terms of regulatory burden, transparency and the risk of inefficient allocation of resources.

Another option open to authorities to cushion the effect of foreign capital outflows is to promote the repatriation of capital from abroad. As noted in the previous section, this counteracting effect is relatively frequent, particularly in periods of financial stress. However, empirical evidence shows that this phenomenon is much more pronounced in countries which have well-developed institutions, whose economy has been managed prudently and which have ample international reserves (Alberola et al., 2016).

Clearly, too, the implications of a sudden stop in capital inflows are potentially greater in countries which have previously received massive inflows. High capital inflows may generate financial and real asset price bubbles in recipient countries, and preventing excesses of this type is crucial for reducing the impact of their possible reversal. For this reason, and contrary to what was said above for moderating the impact of a sudden stop in capital inflows, the possible measures to be adopted include exchange rate appreciation, reserve accumulation (without increasing the monetary base), the tightening of monetary and fiscal policies and, where applicable, capital inflow management measures. Recently some macroprudential tools have been added to this list, particularly when the flows are channelled through the banking system. Hoggarth et al. (2016) report that both the countercyclical capital buffer and the liquidity buffers recently established by Basel may play an important role in this respect, although here it is important that the reciprocity rules between countries be applied as envisaged under legislation.

In any event, it must be kept in mind that any international capital flow involves at least two countries: the recipient and the issuer. Although this article focuses on recipient countries, issuing countries also have a role to play in ensuring global financial stability, particularly when it is taken into account that global financial conditions seem to be what mainly determine these flows, at least in the most recent period. The authorities of countries which are net issuers on a sustained basis over time also have to look at which factors inhibit the return on investment in their country and question whether the way in which capital is being exported reduces or exacerbates global financial instability. Countries 
which, owing to the monetary policies they are applying in a specific situation, generate capital flows to third countries, must take into account the possible transmission effects of these policies above and beyond their purely domestic effects.

From this standpoint, international coordination is an imperative constant. Three main initiatives have been taken to coordinate and clarify capital flow management measures (CFMs) and macroprudential measures (MPMs): i) the OECD Code of Liberalisation of Capital Movements; ii) the IMF's Institutional View; and iii) the G20 Coherent Conclusions. Although these three initiatives differ in nature, they are mutually complementary and consistent and have been progressively revised since their introduction to adapt them to the changing circumstances (IRC Task Force on IMF issues, 2016).

The OECD's Code of Liberalisation of Capital Movements (the code) has been in force since 1961 and provides a balanced framework for all adhering countries to progressively remove barriers to the movement of capital. The countries undertake not to introduce CFMs, although the code allows some flexibility under certain circumstances, ${ }^{6}$ which requires the application of a series of principles (transparency, non-discrimination, proportionality and accountability) to avoid or minimise adverse collateral effects. The code is legally binding on adhering countries (in principle, all OECD countries, although since 2012 it is open to other countries). The OECD has been revising the code since March 2016 to enhance and ensure its relevance, and expects to have finished the task by 2018.

The IMF's Institutional View on Liberalisation and Management of Capital Flows (IV) was implemented in 2012. Its purpose is to provide the IMF with a clear and consistent basis on which to make recommendations to all its members on policies associated with capital movements. ${ }^{7}$ The IV is not binding; however, the Integrated Surveillance Decision requires the IMF to assess capital flow policies which may significantly impact the stability of the balance of payments or affect other countries, with implications for global stability. In 2016 the IMF reviewed the use of the IV since 2012, concluding that the economic policy responses since 2012 have generally been in line with this guidance.

Lastly, the G20 Coherent Conclusions (CC), adopted in 2011, set out a wide range of nonbinding principles on how to cope with large capital flows. National authorities may impose restrictions on capital movements under specific circumstances (to address systemic financial risks), provided these measures are not used as a substitute for the application of appropriate macroeconomic policies. The capital movement measures should generally form part of broader packages which include appropriate monetary, exchange rate, reserve management and prudential policies. In 2016 and 2017, the G20 resumed the analysis and monitoring of capital flows and their risks, with emphasis on aspects such as achieving greater consistency in international organisations' guidance on capital flow management measures, particularly MPMs.

\section{Conclusion}

The last few decades have shown how the globalisation of financial markets poses significant challenges for the international community. Cross-border capital flows bring considerable benefits for recipient economies, but may also be a source of volatility and

6 The transactions on which capital controls may be imposed (temporarily and in proportion to the risks) are grouped into two lists. Most macroprudential measures fall outside the sphere of action of this code.

7 A basic principle in this respect is that use should be made of CFMs when other economic policy options have been exhausted, although they may be useful under certain circumstances (when a country is in crisis or facing imminent crisis, etc.). It may also be worthwhile using them in conjunction with macroeconomic policies if the latter take time to yield results. 
risk, particularly for countries with poor-quality institutions and insufficiently developed local financial markets. Against this backdrop, the recommendations of international organisations point to the need to foster, in the economies receiving these flows and particularly in the emerging countries, a stable macroeconomic environment and sound institutions attracting long-term capital flows. Under specific circumstances, it may be necessary to implement temporary capital flow management measures, which should complement, but never replace, the structural reforms and macroeconomic adjustment needed by economies.

\section{REFERENCES}

AHMED, S., COULIBALY, B. and ZLATE, A. (2015). International Financial Spillovers to Emerging Market Economies: How Important Are Economic Fundamentals?, International Finance Discussion Papers, No 1135, Board of Governors of the Federal Reserve System

ALBEROLA, E., A. ERCE and J. M. SERENA (2016). "International Reserves and Gross Capital Flow Dynamics", Journal of International Money and Finance, Vol. 60, pp. 151-171.

ALONSO, I. (2015). Institutional Drivers of Capital Flows, Banco de España Working Paper 1531.

BLUEDORN, J., DUTTAGUPTA, R., GUAJORDO J. and P. Topalova (2013). Capital Flows are Fickle: Anytime, Anywhere, IMF Working Paper, No 13/183, August.

BRUNO, V. and H. S. SHIN (2015). "Capital Flows and the Risk-taking Channel of Monetary Policy", Journal of Monetary Economics, Vol. 71, pp. 119-132.

CABALLERO, R. J., E. FARHI, P. O. GOURINCHAS (2015). Global Imbalances and Currency Wars at the ZLB, NBER Working Paper, No. 21670.

CERUTTI, E., ClAESSENS, S. and D. Puy (2015). Push Factors and Capital Flows to Emerging Markets: Why Knowing Your Lender Matters More Than Fundamentals", IMF Working Paper, No 15/127, June.

CHINN, M. D. and H. ITO (2006). "What matters for financial development? Capital controls, institutions, and interactions", Journal of Development Economics, 81, pp. 163-192.

COMMITTEE ON THE GLOBAL FINANCIAL SYSTEM (CGFS) (2009). Capital Flows and Emerging Market Economies", CGFS Papers, No 33.

EICHENGREEN, B. and P. GUPTA (2014). Tapering Talk: The Impact of Expectations of Reduced Federal Reserve Security Purchases on Emerging Markets, Policy Research Working Paper Series, No 6754, The World Bank, January

- (2016). "Managing Sudden Stops", Mimeo, Presented at the 14th Emerging Markets Workshop: "Spillovers and spillbacks from major transitions in the global economy", November, Banco de España.

FRATZSCHER, M. (2012). Capital flows, push versus pull factors and the global financial crisis, Journal of International Economics, vol. 88, No 2, pp. 341-356.

FRATZSCHER, M., LO DUCA, M. and R. STRAUB (2013). On the International Spillovers of US Quantitative Easing, DIW Berlin Discussion Paper, German Institute for Economic Research.

FUERTES, A. and J. M. SERENA (2015). How firms borrow in international bond markets: securities regulation and market segmentation, Banco de España Working Paper 1603

FURCERI, D. and P. LOUNGANI, P. (2015). Capital Account Liberalization and Inequality, IMF Working Paper, No 15/243, November

GHOSH, A., QURESHI, M., KIM, J. and J. ZALDUENDO (2014). "Surges", Journal of International Economics, Vol. 92, No 2, pp. 266-285

GOURINCHAS, P. and O. JEANNE (2013). "Capital Flows to Developing Countries: The Allocation Puzzle", Review of Economic Studies, Vol. 80, pp. 1484-1515.

HOGGARTH, G., C. JUNG and D. REINHARDT (2016). Capital Inflows -the Good, the Bad and the Bubbly, Financial Stability Papers 40, October, Bank of England.

IMF (2016). Capital Flows -Review of Experience with the Institutional View, International Monetary Fund document, November.

IRC TASK FORCE ON IMF ISSUES (2016). Dealing with large and volatile capital flows and the role of the IMF, ECB Occasional Paper Series, September.

KOSE, A., PRASAD, E., ROGOFF, K. and S. WEI (2009). Financial Globalization: A Reappraisal, IMF Staff Papers, Vol. 56, No 1, pp. 8-62, April.

MIRANDA-AGRIPPINO, S. and H. Rey (2015). World Asset Markets and the Global Financial Cycle, NBER Working Paper, No 21722, November.

MISHKIN, F. (2007). "Globalization and Financial Development", Speech to the New Perspectives on Financial Globalization Conference, Washington, D.C.

OBSTFELD, M. (2005). "Reflections upon rereading 'The Capital Myth'”, mimeo.

PRASAD, E., RAJAN, R. and A. SUBRAMAIAN (2007), "Foreign Capital and Economic Growth", Brooking Papers on Economic Activity, Vol. 38, No 1, 153-230.

REY, H. (2015). Dilemma not Trilemma: The Global Financial Cycle and Monetary Policy Independence, NBER Working Paper, No 21162, May.

RODRIK, D. (2007). "How to Save Globalization From Its Cheerleaders", The Journal of International Trade and Diplomacy, Vol. 1, No 2, pp. 1-33. 
RODRIK, D. and A. SUBRAMANIAN (2009). Why did Financial Globalization Disappoint?, IMF Staff Papers, Vol. 56, No 1, pp. 112-138.

SARNO, L., TSIAKAS, I. and B. ULLOA (2016). "What Drives International Portfolio Flows?", Journal of International Money and Finance, Vol. 60, Issue C, pp. 53-72.

TURNER, A. (2010). "After the crisis: Assessing the Costs and Benefits of Financial Liberalization", 14th Chintaman Deskmukh Memorial Lecture, Reserve Bank of India.

WORLD BANK (1997). "Private Capital Flows to Developing Countries: the Road to Financial 